\title{
Aleksandra Augstumu dziednīcas baznīca
}

\author{
Vladimirs Kuznecovs
}

Tā saukto Dievam tīkamo iestāžu atklāšana 1824. gadā Aleksandra Augstumos bija nozīmīgs notikums plašas iedzīvotāju grupas, galvenokārt nabagu un slimo apgādībā un ārstēšanā. Šìs iestādes ietvēra ne vien medicīniskas (psihiatrisko, venerisko, somatisko) nodaḷas, bet arī vairākas sociālas iestādes - labošanas iestādes arestantiem, bezdarbniekiem un klaidoņiem, kā arī nabagmāju, kurā tika uzturēti gan nespējnieki, gan bērni un pusaudži. Visiem šiem dzives atstumtajiem, kurus apsargāja apstākḷlos, kas atgādināja cietumu, bija nepieciešama ne vien medicīniskā un sociālā palīdzība, bet arī dvēseles dziedināšana, ko uzskatīja par nozīmīgu "morālās terapijas" (šodien mēs teiktu - psihoterapijas) paveidu.

Par mūsu dienās neesošo Aleksandra Augstumu dievnamu, kas 2006. gada maijā būtu svinējis savas iesvētišanas 180. gadadienu, vēsture saglabājusi pieticīgu, mazpazīstamu Rīgas draudžu vēstures lappusi. Tā ir saistīta gan ar novada psihiatrijas vēsturi, gan arī ar paša novada vēsturi kopumā. Dievnama vēsture, ko mēs pirmoreiz mēǵinām atainot šajā rakstā, no pašiem pirmsākumiem ir neskaidra. Jau 19. gadsimta 80. gados Aleksandra Augstumu administrācija savā atbildē Vidzemes sociālās aprūpes kolēǵijai uz tās pieprasījumu bija spiesta konstatēt: "...par Aleksandra Augstumu baznīcu bija grūti savākt ziņas" [1]. Mūsdienu avīze "Svētdienas Rīts", atzīmējot Sarkandaugavas Sv. Trīsvienības draudzes 30 gadu jubileju 1999. gada 4. novembrī (22. oktobrī - pēc vecā stila), rakstīja: "...kā mums zināms no vēstures liecībām, Sv. Trīsvienības draudze oficiāli dibināta 1869. gada 22. oktobrī... 1871. gada februārī Rìgas pilsētas varas iestādes nodeva jaunās draudzes rīcībā koka baznīcinu (tagadējā Preobraženska pareizticīgo baznīca), kas bija uzcelta 1826. gadā. Ir pamats uzskatīt, ka pirms tam dievkalpojumi notika Aleksandra Augstumu slimnīcas telpās (tagad Sarkandaugavas Psihoneirolog̣iskā slimnīca), kuras celtniecību pabeidza 1824. gadā" [2]. Tomēr agrīnā Aleksandra Augstumu dievnamu vēsture ir daḷeji izklāstīta dokumentā, ko 1876. gada 5. augustā parakstīja Sarkandaugavas Sv. Trīsvienības luteriskās baznīcas administrācija. Saskaņā ar to, kā arī ar citiem tālaika avotiem, atklāšanas gadā (1824) Rīgas mag̣istrāts Aleksandra Augstumu iestādei dāvinājis prāvu 
zemes gabalu lūgšanas nama un kapu ierīkošanai. Līdz dievnama būves pabeigšanai tā funkcijas veica lūgšanu istaba, kuru 1824. gadā iekārtoja, pateicoties Aleksandra Augstumu iestāžu Uzraudzības komitejai. Dievkalpojumus šajā lūgšanu istabā noturēja luterāṇu Jāṇa draudzes virsmācītājs J. H. Trejs (J. H. Trey, 1794-1849) vācu un latviešu valodā, un mācìtājs Taubenheims (Taubenheim) igauṇu valodā. No pilsētas pie saviem "garīgiem bērniem" brauca arī citi mācītāji [2]. Celtnes projekta arhitekts bija J. A. Špacīrs (J. A. Spazier, dz. ap 1790miris pēc 1870), kurš nomainīja mirušo arhitektu K. F. Breitkreicu (K. F. Breitkreuz, 1781-1820), kas bija projektējis Aleksandra Augstumu iestāžu kompleksu. 1825.-1827. gadā Špacīrs aktīvi piedalijās Aleksandra Augstumu iestāžu paplašināšanā [3].

Pēc Sv. Trīsvienības baznīcas ziṇām, dievnams tika uzcelts, izmantojot luterticīgo savāktos ziedojumus (5000 rubḷu). Darbuzṇēmuma līgumu parakstīja ar Rīgas tirgotāju Bornhauptu (Bornhaupt), kas agrāk (1819-1823) bija uzcēlis Aleksandra Augstumu iestāžu kompleksu. Dievnamu iesvētija 1826. gada 31. maijā, piedaloties daudziem viesiem ar Rīgas civilgubernatoru priekšgalā, četrās tolaik izplatītās valodās - krievu, vācu, latviešu un igauṇu. Sākumā dievnams bija paredzēts visām galvenajām konfesijām. Iesvētīšanas dievkalpojumu noturēja génerālsuperintendants Zontags (K. G. Sonntag, 1765-1827) un luterāṇu draudžu mācitāji Trejs un Taubenheims, pareizticīgo virspriesteris Djakonovs u. c. Katoḷu baznīcas pārstāvji dievkalpojumos nepiedalījās, jo bija izvirzījuši ipašas prasības.

Dievkalpojumus pēc kārtas noturēja luterāṇu un pareizticīgo mācītāji dažādās valodās. No 1826. līdz 1828. gadam katru ceturtdienu dievkalpojumus vadīja mācītājs Širrens (Schirren), vēlāk mācītāji mainījās. No 1851. gada kalpoja pastāvīgs mācītājs - Blumenbahs (Blumenbach) [4]. Pēc uzraudzības komitejas 


\section{Kuznecovs}

atskaites datiem, 1826. gadā vairākums Aleksandra Augstumu iestādes iemītnieku, arī slimnieki, nespējnieki un arestanti, bija luterticīgi, otrā vietā bija pareizticīgie (1. tab.).

1. tab. Aleksandra Augstumu iestāžu iemītnieku konfesionālā piederība 1826. gadā (LVVA, 30. f., 2. apr., 7. lieta, 34. lp.)

\begin{tabular}{|l|c|}
\hline Luterticīgie & 219 \\
\hline Pareizticīgie & 74 \\
\hline Katolị & 48 \\
\hline Vecticībnieki & 2 \\
\hline Kalvinisti (reformāti) & 4 \\
\hline Dažādi & 31 \\
\hline Nezināmi Kopā: & 362 cilvēki \\
\hline \multicolumn{2}{|r|}{}
\end{tabular}

Pēc kāda vēlīna krievu autora ziņām, baznīca nosaukta Sv. Trīsvienības vārdā un tā bijusi "pieticīga, zema koka èka". Kāda laikabiedra uztverē baznīca bijusi "l̦oti mājīga celtne" [5]. 1824. gadā Aleksandra Augstumu iestāžu lūgšanas istabas atklāšanas laikā Rīgas Bībeles biedrība dāvinājusi tai Bībeles četrās valodās latviešu, igauṇu, vācu un zviedru valodā [6]. Daudz dāvanu baznīca saṇēmusi iesvētī̌šnas laikā. Altārs bijis izgreznots ar dārgu samta pārklāju ar zelta rotājumiem - tas bijis A. Vērmanes (A. Woermann) dāvinājums. Virs altāra 1826. gadā bijusi Leonardo da Vinči slavenās freskas "Svētais vakarēdiens" kopija, kuru, iespējams, dāvinājis iestāžu ārsts R. Langenbeks (R. Langenbeck, 1772-1835), kurš ziedojis vēl vairākas citas svētbildes. Krucifiksu un altāra evaṇgéliju senslāvu valodā greznā apvākojumā dāvinājis Rīgas tirgotājs Pastuhovs. Dievnamu rotājis arī pestîtāja galvas ǵipša bareljefs. Par ziedojumiem tika iegādātas nelielas ērǵeles. 1826. gadā par ērgelnieku kalpojis kāds aprūpējamais. Baznīcas piederumu skaitā ietilpa vēl ğipša un sudraba krucifiksi, dievmaizišu trauki, sudraba kristāmtrauks (datēts ar 1868. g.), katafalks. Dievnamu apgaismoja divas lielas lustras un seši daudzžuburu svečturi.

Baznīcas pagalms bijis 40 asu liels (viena ass līdzinās 1,7-1,8 kvadrātmetriem), to ietvēris vītolu un apšu dzīvžogs. Sākumā zvanu torṇa nebija, bet dievnamam dāvinātais zvans bijis piekārts starp kokiem [7]. Dievnama atrašanās vietu kāds pareizticīgo avots (1878) raksturo šādi: "Kirka, kas atrodas uz laukuma iepretī Vidzemes sociālās aprūpes kolēgijas iestādēm Aleksandra Augstumos..." [8]. Galvenais ārsts (1884-89) J. Girgensons (J. G. O. Girgensohn, 1833-?) raksta, ka dievnams bijis kapu tuvumā. Šie kapi līdz 1950. gadam atradās zemes gabalā starp dzelzceḷu un Sarkandaugavas ielu, tagadējās Sv. Trīsvienības luterāṇu baznīcas tuvumā [9]. Pēc iestāžu direktora (1879-84) ārsta E. Rutkovska (Eduard Rutkovski, 
1831-1884) liecības, luterāṇu dievkalpojumi (iespējams arī citi) bija galvenokārt paredzēti cietumniekiem, kam bija jāaiziet no iestādes pēc pārmācību un darba nama likvidēšanas 19. gs. 70. gados [10].

Zìmīgas pārmaiņas Aleksandra Augstumu baznīcas vēsturē notika kopš 19. gs. 40. gadiem. Tās bija saistìtas ar dažādiem demogrāfiskiem, sociālekonomiskiem un medicīniskiem faktoriem, kam bija arī reliǵiozs un politisks raksturs. Sarkandaugavas rajonā notika straujš ekonomisko aktivitāšu pieaugums: tika ierīkoti moli, būvēti dambji, gar upi veidoti prospekti, padziḷināts kuǵu cel̦šs, izveidota ziemas osta. Nodibināti arī dažādi saimnieciski uzṇēmumi, piemēram, zāgèetava un Vērmaņa jaunākā (J. Ch. Woermann, 1784-1843) čuguna rūpnīca, par kuras naudu dievnams tika iekārtots. "19. gs. sākumā visas Daugavas grīvas, it ìpaši Sarkandaugavas (Rīgas strādnieku nomales), intensīva attīstỉba pievilināja daudz cilvēku" [11]. Aleksandra Augstumu iestāde bija pārpildīta. 1837. gadā tajā tika uzcelts liels trīsstāvu darba nams, kuru pēc tā slēgšanas 1869. gadā pārveidoja par slimnīcu. Pakāpeniski, it īpaši pēc Dr. Brucera (Gregor Brutzer, 1834-1883) privātklīnikas (tajā uzṇēma tikai ārstējamus pacientus) atklāšanas 1862. gadā, slimnīcas psihiatriskā nodal̦a tika pārpildīta, to pārveidoja par patversmi hroniskiem slimniekiem. Šajā laikā (1860) lūgšanu namam piebūvēja zvanu torni un sakristeju [12]. Tomēr šì vecā baznīciṇa, kas apkalpoja gan Aleksandra Augstumu iestāžu iemītniekus, gan arī arvien skaita ziṇā pieaugošos apkārtnes iedzìvotājus, sen jau nespēja ietilpināt visus ticīgos, tāpēc 19. gs. 50. gados luterāņu un pareizticīgo (to balss gan vēl skanēja klusu) baznīcu valdē radās doma par īpašas draudzes dibināšanu; to atbalstīja lielo fabriku vācu strādnieki un amatnieki. Šo draudzi pievienoja Doma draudzei, kurā uzñēma arī latviešu draudzes locekḷus.

1857. gadā Domes draudzes mācītājs Haralds Pēlhavs (Harald Poelchau) ierosināja Rīgas Konsistorijas iecirkṇa sinodē izveidot atsevišku pastorātu un iestādi ar pastāvīga mācītāja statusu. Šis priekšlikums sāka virzīties uz priekšu tikai 1866. gadā, kad Rīgas Rāte nodibināja komisiju, kuru vadīja birgermeistari Gross (Gross) un Millers (Miller) un rātskungi Berkholcs (Berkcholz) un Beks (Beck). 1867. gada 13. novembrī Rīgas Rāte Sarkandaugavā izveidoja jaunu iecirkni "Sv. Trīsvienība", kuru iekšlietu ministrs apstiprināja 1869. gada oktobrī [13]. Sarakstē starp Iekšlietu ministriju, Vidzemes kolēgiju, pilsētu un Rīgas genenēālgubernatoru, kas aizsākās 1870.-1871. gadā, tika apspriests jautājums ne tikai par baznīcas èkas nodošanu luterāṇu draudzei, bet arī par iespēju tajā turpināt pareizticīgo dievkalpojumus [14]. Sarunas ar Vidzemes sociālās aprūpes kolēgiju par Aleksandra Augstumu iestādes baznīcas atvēlēšanu jaundibinātajai draudzei beidzās 1871. gada februārī, bet jūlijā lūgšanu namu pārṇēma Sv. Trīsvienības draudzes administrācija. 1871. gada 27. jūnijā par tās pirmo mācītāju tika iecelts Kārlis Froms (Karl Fromm). Pastāvīgu Aleksandra Augstumu mācītāju līdz tam finansēja pilsēta; piemēram, zināms, ka igauṇu mācītājs līdz 1867. gadam saṇēma 66 rubl̦us un 50 kapeikas gadā, bet Aleksandra Augstumu iestāde viņu apgādāja ar ekipāžu. Bez tam pēc tradīcijas iestādes personas varēja atsevišḳi ziedot līdzekḷus 


\section{Kuznecovs}

draudzei vai tieši mācītājam. Kad Aleksandra Augstumu lūgšanu namu pārṇēma Sv. Trīsvienības draudze, nebija vairs nepieciešamības algot atsevišķu mācītāju, jo noteikumi paredzēja, ka draudzes mācītājam ir jāapkalpo arī šis lūgšanu nams.

Draudze strauji palielinājās. Šajā laikā tajā bija jau 7000 luterticīgo, bet baznīcā bija tikai 100 sēdvietu, tāpēc baznīcas administrācija nolēma celt jaunu baznīcu. Laikā no 1876. līdz 1878. gadam Sarkandaugavā tika uzcelta jauna Sv. Trīsvienības baznīca, bet lūgšanu namu atdeva atpakal iestādei, kas to neizmantoja - tas stāvēja tukšs. Jaunās baznīcas draudze bija liela, mācītājs nesaṇēma algu par blakus atrodošās draudzes apkalpošanu. Tas radīja konflikta situāciju: mācītājs varēja pēc savas patikas noturēt vai nenoturēt lūgšanu dievnamā. Viņš nosūtỉja vēstuli iestādes pārvaldei, kas to pārsūtīja Vidzemes kolēgijai 1880. gada 15. februārī. Vēstulē viņš interesējās, kādas attiecības iestāde vēlas uzturēt ar Sv. Trīsvienības baznīcu [15]. Šajos gados pastors Froms izṇēmuma kārtā bija piekritis nokristìt jaundzimušo, kurš bija dzimis Aleksandra Augstumos (tajā bija arī bērnu patversme) [16]. Iestādes pārvalde uzskatīja par savu pienākumu atlīdzināt mācītājam arī par brīvprātīgajiem sprediḳiem. Pārvalde bija ieinteresēta, lai iestādei būtu pastāvīgs mācītājs, kas apkalpotu apm. 132 slimniekus. Aleksandra Augstumu iestāde ar direktoru E. Rutkovski priekšgalā savā 1880. gada 8. maija vēstulē Vidzemes sociālās aprūpes kolēǵijai lūdza aț̣auju uzcelt jaunu lūgšanu namu, bet veco namu nodot pārvaldei īpašu dievkalpojumu noturēšanai un sanāksmēm [17]. Tomēr notika savādāk.

19. gs. 40. gados daudzi vietējie iedzīvotāji vēlējās pāriet pareizticībā. Tāpēc pareizticīgo baznīcas centieni organizēt Sarkandaugavā īpašu draudzi ar līdzekḷu un zemes izdalīšanu dievnama celtniecībai kḷuva enerğiskāki. Pēc pareizticīgo baznīcas avotiem, pirmie mēgeinājumi šajā virzienā bija saistīti ar pirmā Rīgas pareizticīgo bīskapa Irinarha (Popova) darbību. Citos avotos norādìts, ka nozīme bijusi slavenā pareizticīgo baznīcas vēsturnieka un teologa bīskapa Filareta (D. Gumili levska, t. s. Filareta I; 1805-1866) centieniem. Rīgas vikāra amatā virsgans stājās 1842. gada 2. jūnijā un ieṇēma to lìdz 1848. gada novembrim. Ar Sinodes sniegto kredītu viņam izdevās atklāt daudz dievnamu lauku apvidū. "Toties baznìcas celšanai Rīgā līdzekḷus iegūt neizdevās. Bija grūtības arī ar zemes iegūšanu šim mērḳim. Neraugoties uz to, bīskaps Filarets uzsāka sarunas par baznīcas celšanu Sarkandaugavā" [18]. Baznīcas centienus atbalstīja laicīgā vara, kas parasti uzturēja saimniecisku, pat draudzīgu politiku attiecībās ar baltvāciešiem. Tā, piemēram, savā 1849. gada maija rakstā Sinodei Rīgas generālgubernators (1848-1861) kṇazs Aleksandrs Suvorovs norādijja, ka Aleksandra Augstumu iestādēs uzturas lìdz pat 150 pareizticīgo, iestāžu tuvumā atrodas arī fabrikas, kurās pastāvīgi strādā ap 600 pareizticīgo strādnieku. Pēc Suvorova domām, reliǵisko rituālu veikšana viniem saistìta ar dažādām grūtībām, tādēl viņš lūdz Sinodes palīdzību pareizticīgo dievnama un baznīcas draudzes skolas celtniecíbai [19]. Sīs rūpes turpināja Filareta pēctecis - jaunizveidotās Rīgas eparhijas galva (1848-1867) arhibīskaps Platons (Gorodeckis), kurš 1849. gada 2. jūlijā atkārtoti vērsās Sinodē ar lūgumu par pareizticīgo dievnama celtniecību Sarkandaugavā. Sinode viṇam ieteica saistīties ar 
vietējo varu. "Pilsēta ir viņam pretimnākoša un iedala bez atlīdzības zemesgabalu būvei. 1850. gada oktobrī eparhijas pārvalde uzdod izstrādāt arhitektūras projektu un celtniecības tāmi koka baznīcai 300 cilvēkiem" [20]. Lai uzsāktu darbu, savāktie līdzekḷi (393 rubḷi un 90 kapeiku) izrādijjās nepietiekami. Pareizticīgo dievnama celtniecība atkal tika atlikta. Šoreiz vēl uz 20 gadiem. Pēc tam kad Sarkandaugavā tika uzcelta (1876-1878) jauna Sv. Trīsvienības baznīca, vecā ēka palika stāvam tukša. Tālaika pareizticīgo galva (1877-1882) bīskaps Filarets (Filaretovs, t. s. Filarets II) 1. oktobrī uzaicināja tuvākās latviešu un krievu pareizticīgo Pokrovas baznīcas mācītāju (1859/1860-1879) Vasiliju Reinhauzenu, kurš dažkārt noturēja dievkalpojumus arī Aleksandra Augstumu iestādēs, apmeklēt paredzētās baznīcas celtniecības vietu. Reinhauzens konstatēja, ka šis zemesgabals ir jau aizṇemts citām vajadzībām: šeit tika uzcelta aptiekas māja, mācītāja māja un luterāṇu skola [21]. 1878. gada 10. novembrī virsgans Filarets vērsās pie Vidzemes gubernatora grāfa A. fon Ukskila-Gillenbanda (Graf Alexander von Uxküll-Gyllenband) ar lūgumu piekāpties un kopā ar likvidēto baznīcu (ko plānoja pārbūvēt par pareizticīgo dievnamu) atdot arī zemesgabalu, uz kura tā atrodas. Atteikuma gadỉjumā bija paredzēts izmantot baznīcu par celtniecības materiālu jaunā dievnama būvei [22]. Savu lūgumu Filarets atkārtoja 1878. gada 14. novembrī un 1879. gada 24. augustā [23]. Tomēr Rīgas gubernators atteicās apmierināt lūgumu, motivējot atteikumu ar to, ka Rīgas maǵistrāts lūdzis atdot veco ēku evaṇgéliski luteriskajiem spredikikiem. Turklāt sociālās aprūpes kolẹgija nebija atteikusies no domas tukšajā dievnamā atjaunot starpkonfesionālos dievkalpojumus. Tas negaidīti visu sarežğija. 1881. gadā Rīgas katoḷu baznīcas pārzinis kapelāns Marcinovskis piekrita reizi mēnesī sūtīt uz Aleksandra Augstumiem ksendzu ar noteikumu, lai tur būtu dievkalpojumam atbilstošas telpas un ksendzs apgādāts ar ekipāžu [24]. Luterān̨u puse, ko pārstāvēja Sv. Trīsvienības baznīca, ar pilsētas valdes piekrišanu 1884. gada 20. februārī atdeva atpakal Aleksandra Augstumu administrācijai slimnīcas baznīcas īpašumu un baznīcas ziedojumus 383 rubl̦ us un 41 kapeiku [25]. Lìdz slimnīcas baznīcas nojaukšanai dievkalpojumi nenotika. Pēc Aleksandra Augstumu iestāžu direktora Girgensona ziṇām, slimnīcai bijusi tikai lūgšanu istaba, kas atradusies slimnīcas èkas pagrabstāvā blakus lịķu kambarim un morgam [26].

Pēc imperatora Aleksandra II noslepkavošanas 1881. gada 2. martā politiskais klimats valstī acīmredzami mainījās no diezgan liberāla uz konservatīvi aizsargājošu, prokrievisko pusi. Tas nevarēja neatspoguḷoties Baltijas baznīcu situācijā. Jaunas vēsmas Sarkandaugavas dievnama celtniecībā sākās Rīgas un Mītavas (Jelgavas) bīskapa Donāta (Sokolovs-Bobrinskis) Rịgas laikā (1882-1887). Ar viṇa svētību hospitālās Sv. Trīsvienības baznīcas mācīājam protohierejam N. M. Popovam tika uzdota līdzekḷu vākšana: gada laikā tika savākti 1860 rubḷi. Kopsummā ar agrāksavāktajiem līdzekḷiem bija aptuveni 3000 rubl̦u, bet baznīcas celtniecība atkal tika atlikta, jo mağistrāts atteicās dot jaunu zemesgabalu (agrāk piedāvātais tika apbūvēts), ko bija lūgusi eparhija [27]. Rūpes vainagojās ar panākumiem tikai 1887. gadā, kad bīskaps Arsenijs (Brjancevs) 1888. gada 29. februārī no jauna 


\section{Kuznecovs}

vērsās pie Vidzemes gubernatora M. A. Zinovjeva ar lūgumu piešķirt zemesgabalu bez atlīdzības Sarkandaugavas dievnama celtniecībai. Vienlaikus viņš lūdza aţ̦auju nojaukt veco Aleksandra Augstumu lūgšanu namu celtniecības vajadzībām [28]. Galīgā lēmuma pien̦emšanā piedalìjās daudzas instances - guberṇas un pilsētas varas iestādes, Iekšlietu ministrija, valdošā Sinode, pat personīgi imperators. Protestiem pievienojās dziednīcas administrācija. Piemēram, galvenais ārsts Girgensons savā aicinājumā Vidzemes sociālās aprūpes kolẹgijai (ēkas īpašniecei) 1889. gada 9. martā lūdza saglabāt veco ēku līksu kambara vajadzībām, kas kopā ar morgu un sekciju telpu tajā laikā atradās trīsstāvu ēkas pagrabā zem sieviešu psihiatrijas nodalıs, kas, pēc direktora domām, izraisīja slimnieču psihiskā stāvokḷa pasliktināšanos [29]. Tomēr kolēǵija 1888. gada martā atbalstīja vecā neizmantojamā lūgšanu nama nojaukšanu jaunas celtniecības vajadzībām. Turklāt pamatojumā bija minēts, ka "...tā projektēšana (t. i., vecās baznīcas nojaukšana - V. K.) pareizticīgo dievnamu izbūvei vairāk atbilst tam mērḳim, ko bija paredzējuši šā nama dibinātāji" [30]. To netieši apstiprināja 1887. gada 28. novembra "Rīgas Vēstnesī" agrāk izteiktais apgalvojums, ka Aleksandra Augstumu iestāžu dibinātājs cars Aleksandrs I pavēlējis piešķirt noteiktu naudas summu liela pareizticīgo dievnama celtniecībai [31]. Kolēgija uzlika par pienākumu Pareizticīgo valdei ar Arseniju priekšgalā organizēt vecā lūgšanu nama nojaukšanu uz sava rēķina, kā arī bez atlīdzības noturēt dievkalpojumus "Aleksandra Augstumu iestāžu personālam un iemîtniekiem" [32]. Pēc saskaņošanas ar varas instancēm projekts tika piedāvāts bīskapam. Tā paša gada 10. aprīlī tika saņemta viņa piekrišana [33]. Punktu šai lietai pielika imperators Aleksandrs III. Cars, kas vienmēr bija iestājies par pareizticības interesēm, 1888. gada 8. jūlijā izdeva rīkojumu (ukazu) nākt pretī Rīgas eparhijas vēlmēm vecās ēkas nojaukšanas lietā, par ko tika ziṇots Iekšlietu ministrijai 19. jūnija rakstā Vidzemes gubernatoram [34]. Pilsēta bija spiesta piekāpties un atbalstìt celtniecības ideju. Iedalītais zemesgabals atradās nedaudz tālāk no Aleksandra Augstumu iestādēm blakus Mīlgrābenes (Mīlgrāvja) dzelzceḷa stacijai ar tādu pašu nosaukumu - Aleksandra Augstumi (tagad Sarkandaugava) [35]. Vecās slimnīcas baznīciṇas èka tika nojaukta jaunās būves vajadzībām. Virsgana Arsenija 1888. gada 24. augusta rakstā, kas adresēts Vidzemes kolēgijai, tiek runāts par ēkas pieṇemšanu un pazīstamā latviešu Debesbraukšanas pareizticīgo baznīcas mācītāja (1879-1909) virspriestera Andreja Kangera [36] paredzēto tikšanos ar kolēgiijas pārstāvi [37]. Norādītajā vietā tika uzcelta līdz pat šai dienai pastāvošā koka ēka - Preobraženska baznīca. Tā tika iesvētìta 1890. gada 5. maijā, izveidojot arī pareizticīgo draudzi. Tikai 1906. gadā dziednīcas teritorijā jaunajā vienstāva mūra ēkā izvietoja "kapelu, sekcijas un lị̄u kambaru", kā arī ierīkoja ūdens padevi [38]. Tà Aleksandra Augstumu dievnama vēsture atgriezās pie saviem pirmsākumiem - lūgšanu istabas. Īpaši tika apmaksāti Rīgas baznīcu pakalpojumi par slimnīcas kapu sakārtošanu un apbedijumiem. 1905. gadā proporcionāli dažādu konfesiju mirušo skaitam (to vidū katoḷi bija mazākumā), Sv. Trīsvienības baznīcas pārzinim pastoram Trejam un Preobraženska baznīcas 
pārzinim mācītājam Baranovam katram tika izmaksāti 35 rubḷi, bet Rīgas katoḷu baznīcas pārzinim Afanasovičam - 30 rubḷi [39]. 1930. gadā kapela slimnīcas dokumentos apzīmēta kā èka Nr. 13 ar 200 kvadrātmetru lielu platîbu [40]. Vēl pirms tam, 1928. gadā, tika nojaukta bijušajai slimnīcas baznīcai piederoša maza kapliča, kas bija celta kā piebūve uz ietves pie slimnīcas mūra žoga Aptiekas ielas pusē un paredzēta ziedojumiem. 20. gados tajā atradās piecas svētbildes, uz jumta krusts. Ilgus gadus piebūve bija bez uzraudzības, tās logi izsisti, tāpēc ar Garīgo lietu pārvaldes un Veselības departamenta lēmumu tā tika nojaukta, bet relikvijas pārvietotas uz slimnīcas morgu. Pēc Otrā pasaules kara kapela un slimnīcas kapi tika slēgti. Pati ēka pagājušā gadsimta 60. gados pārbūvēta par divstāvu ēku. Līdz neseniem laikiem tajā atradās laboratorija, bet pirms tam - darba terapijas darbnīcas, dienas stacionārs. Celtniecības vajadzībām tika nojaukta neliela veca koka ēka (galdniecība), kuru daži toreizējie darbinieki vēl šodien sauc par bijušo slimnīcas kapelu. Kapelas atdzimšana Rīgas Psihoneirologiskajā slimnīcā attiecināma uz 20. gadsimta 70. gadu beigām-80. gadu sākumu. Kluba ēkā bija lūgšanu istaba ar latviešu tēlnieka I. Vasiḷjeva-Penerdži (1940-1997) veidoto krucifiksu (pēc tālaika galvenās ārstes Z. Sočñevas mutiskas liecības). Kopš 20. gadsimta 90. gadiem pie smagi slimiem un mirstošiem pacientiem kādu laiku regulāri tika aicināts luterāṇu mācītājs. Mūsdienās luterāṇu dievkalpojumi ar Sarkandaugavas Sv. Trīsvienības luteriskās baznīcas mācìtāja piedalǐšanos notiek ìpašajā jaunā kluba telpā. Pēc radu un tuvinieku vēlēšanās pie pacientiem epizodiski tiek aicināti arī citu konfesiju mācītāji. Lìdz pat šim laikam smagos un nevarīgos pacientus svētdienās regulāri apmeklē Rīgas Sv. Tijādības Sergija pareizticīgo sieviešu klostera mūḳenes.

Aleksandra Augstumu dievnama "mazā" vēsture ir ierakstìta "lielās" pasaulīgās vēstures, arī baznīcas, kontekstā. Reizē ar šauri konfesionāliem faktiem tajā izpaudās vēl daudzi citi - demogrāfiskais, ekonomiskais, etnokulturālais, politiski sociālais un medicīniskais faktors. Dievnama, kā arī visas iestādes tapšanā un pastāvēšanā liela loma bija labdarībai. Dievnamā kalpoja dažādu konfesiju mācītāji. Rodoties luterāṇu draudzei, un it ìpaši pēc tam, kad 1878. gadā Sarkandaugavā tika uzcelta liela luterāṇu baznīca, slimnīcas dievnama nozīme arvien samazinājās lìdz pat tā likvidēšanai ilgi pirms pašas èkas nojaukšanas pareizticīgo draudzes labā. Jau kopš 19. gs. 70. gadu beigām baznīcas dzīve tajā pamira, bet, sākot ar 20. gs. 80. gadiem, lūgšanas notika vairs tikai kapelā.

\section{Vēres}

1. LVVA, 30. f., 1. apr., 2311. 1., 56. 1p.

2. Sarkandaugavas Evaņgēeliski luteriskai draudzei 130 gadu jubileja. Svētdienas Rits, 1999.30.X.

3. Васильев Ю. Классииизм в архитектуре Риги. Рига: 1961, с. 322.

4. LVVA, 30. f., 1. apr., 2311.1., 56. lp., 4; Rigasche Stadtblaetter fuer das Jahr 1826. Riga: S. 177-178. 


\section{Kuznecovs}

5. Шалфеев Б. 100-летие психиатрической лечебницы на Александровской высоте (Историческая справка). Сегодня, 21 сентября 1924; Stadtblaetter fuer das Jahr 1826. Riga: S. 177.

6. Kuzṇecovs V. Labdarības loma psihiatriskās aprūpes tapšanā Latvijā: Aleksandra Augstumiem - 180.//Acta Medico-Historica Rigensia. Vol. VII (XXVI). Rīga: 2005, 187. lpp.

7. LVVA, 30. f., 2. apr., 8. 1., 3. lp. (op); LVVA 30. f., 2. apr., 7. 1., 35. lp. (op), 36.

8. LVVA, 30. f., 1. apr., 2311. 1., 40. lp.

9. Turpat, 97., 98. lp.

10. Turpat, 57.lp.

11. Дёмина Н. Д. Рижская Преображенская Церковь. Исторический очерк. Рига: 2005, с. 11-12.

12. LVVA, 30. f., 1. apr., 2311.1., 56. lp.

13. Turpat.

14. Turpat, 21.-22., lp., 24. lp.

15. Turpat, 57.lp.

16. Turpat, 73. lp.

17. Turpat, 58. lp.

18. Дёмина, see ref. 11, с. 14; Захарьят, Н. По замыслу Петра. Суббота, 2009, 13-19 марта.

19. LVVA, 30 f., 1. apr., 2311. 1., 42. 1p.

20. Turpat; Дёмина, see ref. 11, с. 14-15.

21. LVVA, 30. f., 1. apr., 2311. 1., 42. lp.

22. Turpat, 38., 40. lp.

23. Turpat, 43.-44. lp.

24. Turpat, 74. lp.

25. Turpat, 93. lp.

26. Turpat, 97.-99. lp.

27. Дёмина, see ref. 11, с. 15.

28. LVVA, 30. f., 1. apr., 2311.1., 96. lp.

29. Turpat, 97.-98. lp.

30. Turpat, 100. lp.

31. Turpat, 94. lp.

32. Turpat, 100.lp.

33. Turpat, 102.lp.

34. Turpat, 110. lp.

35. Дёмина, see ref. 11, с. 17.

36. Purviņš K. Pirmās pareizticīgo latviešu draudzes vēsture. Rīga: 1929, 29.30. lpp.

37. Дёмина, see ref. 11, с. 18; Иоаким (архим.), Плисс, В. Преосвященный Арсений (Бряниев) - архиепископ Рижский и Митавский. Рига: 1897, с. 195. 
38. Отчет Лифляндского Приказа общественного призрения за 1907 г. Citēts pēc: Сочнева 3. Г. Рижской Республиканской психиатрической больнице 150 лет.//Психиатрия, невропатология и нейрохирургия. Ч. 1. Рига: 1974, c. 16

39. LVVA, 30. f., 1. apr., 4019. 1., 60. 1p.

40. LVVA, 4578. f., 4. apr., 384. l., 25. lp.

41. LVVA, 1370. f., 1. apr., 917.1., 2., 4., 6., 8. lp.

\section{A History of the Alexander Height Asylum Church in Riga (Summary)}

\section{By Vladimirs Kuznecovs}

The small wooden structure was constructed over the course of two years between 1824 and 1826 . The church was designed by the city architect J. A. Spazier, and consecrated in 1826 upon its completion. Its predecessor, a chapel in one of the asylum's buildings, was opened in 1824, the same year as the asylum itself. The city granted land for the building, while ecclesiastical items (e. g., silver crucifix and baptismal font, New Testament book with ornamented covering, church bell) mostly were donated by private supporters. Services were conducted in four languages (Latvian, Estonian, German, and Russian) by priests and clergy of the different confessions. The majority of prisioners were Lutherans and Orthodox. The parish included not only local residents and factory workers living in the general community, but those with special needs living in charitable residential facilities on the hospital grounds: general medical patients, persons with mental disorders, prisoners, and inhabitants of almshouse (elderly, children, disabled persons, etc). Special needs residential care represented an important service of the asylum as a charitable institution. In 1878 Holy Trinity Church, a large, new Lutheran church was built close to the asylum. After merging with this new parish, the Alexander Height Asylum Church gradually declined in importance. In 1899 it was closed and demolished, and the debris was used to build a small Orthodox church near the asylum. Its church was replaced by the chapel that was closed after the Second World War, and renewed in 1990's.

Vladimirs Kuznecovs, Dr. med.

LU Medicinnas fakultāte

Tālr. 67080204 